\title{
INDEXES OF CITRULLINE METABOLISM IN RAT LIVER UNDER THE TOXIC INJURY AGAINST THE BACKGROUND OF ALIMENTARY PROTEIN DEFICIENCY
}

\author{
H. P. KOPYLCHUK, I. M. NYKOLAICHUK, I. S. LYLYK \\ Yuriy Fedkovych Chernivtsi National University, Ukraine; \\ Institute of Biology, Chemistry and Bioresources, Chernivtsi, Ukraine; \\ e-mail: g.kopilchuk@chnu.edu.ua
}

Received: 29 May 2019; Accepted: 29 November 2019

It is known that citrulline is converted into arginine in the series of metabolic transformations. Results of our previous studies showed that acetaminophen-induced toxic injury on the background of the alimentary deprivation of protein is accompanied by a decrease in arginine level in rat hepatocytes, but citrulline liver metabolism at these conditions remains incompletely clear. In this work, the content of citrulline in the rat liver mitochondrial and cytosolic fractions and the activity of citrulline-degrading enzymes - argininosuccinate synthase and argininosuccinate lyase were investigated. It was found that in the mitochondrial fraction a maximal reduction of the citrulline levels occurred after administration of acetaminophen toxic doses regardless of the protein amount in the ration, while in the cytosolic fraction the alimentary protein deficiency was a key factor in decreasing the activity of argininosuccinate synthase and arginino-succinate lyase. The data obtained indicated the disturbances of the urea cycle functioning and explained the decrease of L-arginine level in hepatocytes in conditions of acetaminophen-induced toxic injury against the background alimentary protein deficiency.

Ke ywords: L-citrulline, argininosuccinate synthetase, argininosuccinate lyase, acetaminophen, toxic injury, alimentary deprivation of protein.

$\mathrm{R}$ ecent scientific data testifies to a close relationship between the nutritional composition of the diet and metabolic status of the organism. The literature often discusses the issue of an increase in the number of diseases associated with defi-ciencies of macronutrients [1,2].

Nowadays, deficiency of protein in a diet is a widespread phenomenon. As a rule, alimentary deprivation of a protein is compensated by the excessive consumption of fast-acting carbohydrates and fats or replacement of a complete food protein with soy isolate. The disadvantage of eating soy protein is that its natural toxins inhibit the activity of trypsin, while soy phytic acid binds to minerals $(\mathrm{Ca}, \mathrm{Mg}, \mathrm{Cu}, \mathrm{Fe}$, $\mathrm{Zn})$ and reduces their absorption by the body $[3,4]$.

Our previous studies [5] have shown that in conditions of inadequate protein nutrition, development of the deficiency dysproteinemia is characteri- zed by total hypoproteinemia and hypoalbuminemia as a manifestation of the disturbance in the synthetic function of the liver.

At the same time, in the context of general availability of a wide range of drugs, there is an issue of their inappropriate use to treat pathological states without proper compliance with the requirements for the drug dosage, treatment regimen and intervals between drug intakes. Quite often, the consequence of uncontrolled self-treatment is an acute toxic injury of the liver.

Literary sources give conflicting data on the advantages of one or another model of toxic liver injury [6]. A model of acetaminophen-induced liver injury is one of the most common [7]. Acetaminophen (Nacetyl-para-aminophenol, APAP) is a drug from the group of agents with analgesic/antipyretic action. Acetaminophen overdose or its use in the presence

(C) 2020 Kopylchuk G. P. et al. This is an open-access article distributed under the terms of the Creative Commons Attribution License, which permits unrestricted use, distribution, and reproduction in any medium, provided the original author and source are credited. 
of different provocative factors, including the lack of essential nutrients, may be accompanied by the development of acute liver failure [8].

Acetaminophen is mostly metabolized by conjugation with sulphate and glucuronate. Depending on the dose, in reactions involving the cytochrome P450 system APAP is converted into a highly reactive metabolite N-Acetyl-p-benzoquinone imine (NAPQI) that reacts rapidly with reduced glutathione (GSH), leading to depletion of the liver stores of glutathione, as it was shown in previous studies [9]. Unconjugated NAPQI binds to proteins and subcell structures, resulting in induction of apoptosis and cell necrosis, and, as a consequence, development of acute liver failure.

An important regulator of the intermediate metabolism in the body is amino acid citrulline, which intracellular concentration defines the levels of L-arginine, synthesized in reactions involving enzymes argininosuccinate synthase (EC 6.3.4.5, ASS) and argininosuccinate lyase (EC 4.3.2.1, ASL) in the urea cycle [10]. Results of the previous studies [11] show that acetaminophen-induced toxic injury on the background of the alimentary deprivation of protein is accompanied by a decrease in arginine levels in hepatocytes.

Protein catabolism and resynthesis of L-arginine from citrulline may partially compensate for the deficiency of L-arginine. In addition, the existence of the inter-organ cycle "arginine - citrulline arginine" with a partial synthesis of citrulline in enterocytes, and metabolism in the kidneys and liver allow protecting the arginine that comes with food from increased degradation in the liver. It is a way of regulation and maintenance of the urea synthesis according to the protein intake by the organism. In this case, arginine is considered the main regulator of urea synthesis, while citrulline plays the role of an important regulator of protein metabolism, especially in conditions of their limited intake $[12,13]$.

Thus, the aim of this research was to study the levels of citrulline and the activity of enzymes of its metabolism in the mitochondrial and cytosolic fractions of rat liver cells in conditions of toxic liver injury against the background of alimentary protein deficiency.

\section{Materials and Methods}

Experiments were conducted on white, nonlinear rats weighing 120-150 g and 2.5-3 months old. All manipulations with laboratory animals were carried out in compliance with the requirements of bioethics in accordance with the "General ethical principles for experiments on animals” (Kyiv, 2011), consistent with the provisions of the European Convention for the Protection of Vertebrate Animals used for Experimental and other Scientific Purposes (Strasbourg, 1986).

During the experiment, in accordance with the norms of the maintenance (3-4 animals of the same sex) rats were kept in plastic cages with a sand layer sterilized in a dry-air sterilizer, with free access to water and food. Rationing of the daily diet was conducted taking into account the principle of dual nutrition [14]. During the experiment, the animals' state was monitored with a daily fixation of weight and amount of consumed food.

Throughout the experiment, the animals received a semisynthetic diet of AIN-93, proposed by the American Institute of Nutrition [15]. Casein was used as a complete protein containing the whole complex of essential amino acids. Given that the index of the biological value of casein is 0.8 due to deficiency of sulfur-containing amino acids, L-cysteine was additionally added to the diet as an amino acid supplement.

The acute toxic injury was induced by oral administration of acetaminophen in the form of a suspension in a $2 \%$ starch gel solution at a daily dose of $1250 \mathrm{mg} / \mathrm{kg}$ for the last 2 days of the experiment [16].

Animals were randomly divided into 4 groups: I - animals that were kept on a balanced semisynthetic ration - control group (C) [15]; II - animals that received semisynthetic low-protein ration for 28 days $(1 / 3$ of the standard daily norm of protein requirement) (LPR) [11]; III - animals with toxic acetaminophen-induced injury maintained on a balanced diet (TI); IV - animals with toxic acetaminophen-induced injury on the background of alimentary deprivation of protein (LPR + TI).

The cervical dislocation of animals was carried out under light ether anesthesia on the $28^{\text {th }}$ and $31^{\text {st }}$ day of the experiment in accordance with current recommendations and ethical standards on anesthesia (Law of Ukraine of February 21, 2006 No. 3447IV "On the Protection of Animals from Cruelty").

The mitochondrial fraction of liver cells was obtained by the method of differential centrifugation [17]. Homogenization medium included $250 \mathrm{mM}$ sucrose solution, $1 \mathrm{mM}$ EDTA, $10 \mathrm{mM}$ Tris-HCl, $\mathrm{pH}$ 7.4. The nuclei and cell fragments were precipi- 
tated by centrifugation at $1000 \mathrm{~g}$ for $10 \mathrm{~min}$. The fraction of the mitochondria from the supernatant was precipitated at $12000 \mathrm{~g}$ for $15 \mathrm{~min}$. The resulting precipitate was washed twice with the medium of subcellular fraction extraction without EDTA.

Microsomal fraction of liver cells was precipitated according to the method described in [18]. The supernatant was used in subsequent studies as a cytosolic (post-microsomal) fraction.

The activity of argininosuccinate synthase and argininosuccinate lyase was determined by the method [19]. The reaction mixture to study the total enzymatic activity of both enzymes contained $40 \mathrm{mM}$ ATP, $70 \mu \mathrm{M} \mathrm{MgSO}_{4}, 80 \mu \mathrm{M}$ L-citrulline, $80 \mu \mathrm{M}$ succinate, $80 \mu \mathrm{M}$ L-aspartate, $0.1 \mathrm{M}$ Tris$\mathrm{HCl}, \mathrm{pH}$ 7.4. The reaction mixture to study the activity of argininosuccinate synthase contained the same ingredients with the exception of a succinate solution. Absorption of the samples was measured on a spectrophotometer CARY 60 (USA) at a wavelength of $515 \mathrm{~nm}$. The activity of argininosuccinate lyase was calculated as the difference between the total activity of the two investigated enzymes and the activity of argininosuccinate synthase.

To determine the citrulline levels, the samples were deproteinized with 10\% TCA solution followed by centrifugation. The obtained supernatant was mixed (in the ratio of 1:10) with the solution consisting of $9.6 \% \mathrm{H}_{2} \mathrm{SO}_{4}, 0.9 \mathrm{mM}$ thiosemicarbazide, $5 \mathrm{mM}$ diacetyl monoxime, and $0.025 \mathrm{mM} \mathrm{FeCl}_{3}$ with the proportion of the quantitative parts 3:1:1:1. The citrulline level in the subcellular fractions was determined spectrophotometrically at the wavelength of $490 \mathrm{~nm}$ by the intensity of the red-purple coloration of the thiosemicarbazide-citrulline-diacetyl monoxime complex [20]. The construction of the calibration curve to determine the amount of citrulline was carried out using a standard citrulline solution followed by a series of dilutions at different concentrations.

The protein level in the samples was determined by the Lowry method [21].

The statistical analysis of the data was carried out using Microsoft Excel 2010. Student's coefficient was used to assess the significance of differences between the two alternative data sets. The $P$-values of less than $5 \%$ were considered statistically significant $(P<0.05)$.

\section{Results and Discussion}

According to research results, the citrulline level in the mitochondrial fraction of liver cells was decreased in all animal groups comparing to the control. The lowest values of this index were recorded in animals with acetaminophen-induced toxic liver injury regardless of the dietary protein intake, which may be considered as a key factor of the established changes (Fig. 1). Taking into account that formation of citrulline in mitochondria occurs with the participation of ornithine transcarbamylase, a decrease in the level of the latter under these experimental conditions is obviously associated with a reduction in the level of one of the substrates of this reaction - ornithine, which was confirmed in our previous studies [11].

As for the levels of citrulline in the cytosolic fraction of rat liver cells, there is another tendency in its concentration changes. Thus, under the conditions of administration of toxic acetaminophen doses against the background of protein deficiency, the levels of citrulline in the studied fraction is twice lower than in animals of the control group (Fig. 2). As seen in the figure, the key factor in these experimental conditions is the deficiency of protein in the diet. Such changes are probably due to enhanced absorption of citrulline from the liver by other organs to maintain the physiological pool of arginine, which is later used in the synthesis of the organism's own proteins and macroergic compounds, in particular, creatine phosphate.

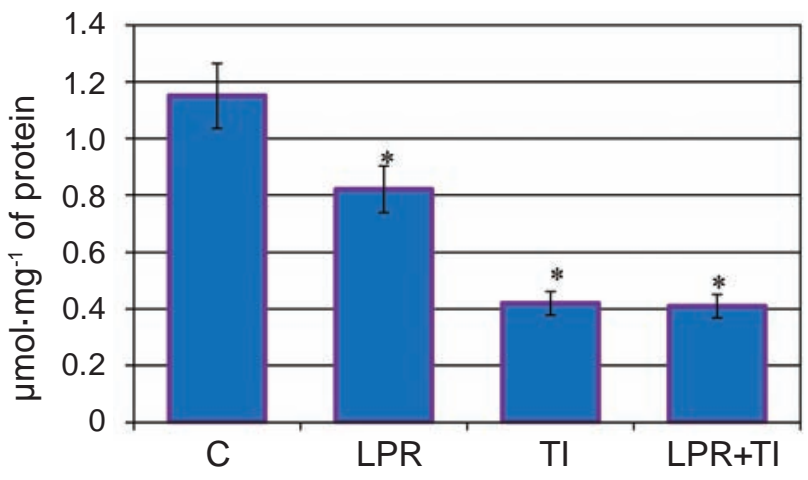

Fig. 1. Citrulline level in the mitochondrial fraction of rat liver cells under the conditions of toxic injury against the background of alimentary protein deficiency. $C$ - animals that were kept on a balanced semisynthetic ration - control group; LPR - animals that received semisynthetic low-protein ration for 28 days; TI - animals with toxic acetaminopheninduced injury maintained on a balanced diet; LPR+TI - animals with toxic acetaminophen-induced injury on the background of alimentary deprivation of protein; *significant difference comparing to control, $P \leq 0.05$ 


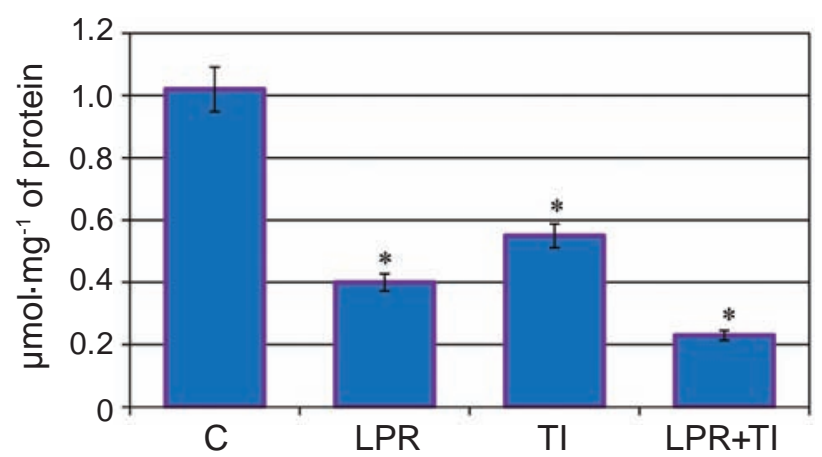

Fig. 2. Citrulline level in the cytosolic fraction of rat liver cells under the conditions of toxic injury against the background of alimentary protein deficiency. $C$ - animals that were kept on a balanced semisynthetic ration - control group; LPR - animals that received semisynthetic low-protein ration for 28 days; TI - animals with toxic acetaminophen-induced injury maintained on a balanced diet; $L P R+T I-$ animals with toxic acetaminophen-induced injury on the background of alimentary deprivation of protein; *significant difference comparing to control, $P \leq 0.05$

It should be mentioned, that citrulline contained in the mitochondria and cytosolic citrulline is, in fact the same citrulline. However, research results showed a multidirectional tendency of changes in the levels of this amino acid in these compartments of hepatocytes, under the influence of the studied factors. As can be seen in Fig. 1 and 2, the absolute values of citrulline level in the subcellular fractions of the liver of animals that were maintained on a low-protein ration differ approximately by half.

It was established in the study of the kinetic mechanisms of antiports in rat liver mitochondria [22], that citrulline is exported to mitochondria by the mechanism of antiport with ornithine. An ornithine/citrulline transporter mediates this antiport associated with proton transport to balance the charge difference between the substrates [23]. Thus, a disturbance in the cellular transport systems may be a reason for the decrease in bioavailability of citrulline as a result of its competition with ornithine.

In addition, the rate at which citrulline is secreted into the systemic circulation is significantly lower than the rate of citrulline absorption. For example, with limited protein intake, the reduced absorption of glutamine by enterocytes contributes to inhibition of the citrulline synthesis, although the level of glutamine and ornithine remains within the limits of physiological values [24]. At the same time, a reduction of citrulline and glutamine absorption by the liver is the result of their impaired transport to blood due to increased absorption of amino acids by enterocytes to synthesize arginine in the intestine and prevent its deficiency [25].

There was an assumption that arginine and citrulline are not absorbed by hepatocytes, but later it has been proved [24] that the liver partially captures these amino acids. In addition, the food intake stimulates the synthesis of proteins in the liver, and, consequently, enhanced absorption of amino acids, which is accompanied by an increase in the portal flow of amino acids.

Consequently, the obtained results are undoubtedly consistent with the existence of an interorgan pathway for the arginine synthesis, which combines the metabolism of glutamine in the intestines and the transformation of citrulline into arginine.

Another important source of citrulline synthesis in the body is the nitrogen oxide system. It is known that arginine under the influence of NO-synthase (EC 1.14.13.39, NOS) is metabolized into two end products - NO and citrulline in the ratio of 1:1. Thus, citrulline can act as a precursor of arginine for the synthesis of NO, defining the main pathways of metabolism and regulation of secondary messenger [26].

To date, the physiological significance of the liver citrulline metabolism remains not entirely clear. It is known that citrulline is converted into arginine in the series of metabolic transformation under the action of enzymes argininosuccinate synthase and argininosuccinate lyase. Therefore, it may be assumed that the absorption of citrulline by the liver serves to synthesize arginine de novo, which further can be used in other intracellular processes.

Recirculation of citrulline with the participation of ASS and ASL plays a key role in maintaining the physiological level of arginine and neutralization of ammonia with the formation of urea. Reduction in the activity of any of the ornithine cycle enzymes leads to the accumulation of ammonia [27].

The results of the studies indicate a decline in the argininosuccinate synthase activity in the cytosolic fraction of rat liver cells in all experimental groups compared to control (Fig. 3). Established changes are probably due to the deficiency of one of the substrates of the reaction - aspartate, which can be intensively used in transamination reactions.

According to literary data [28], the aspartate levels in the cytosol is provided by the malate-as- 


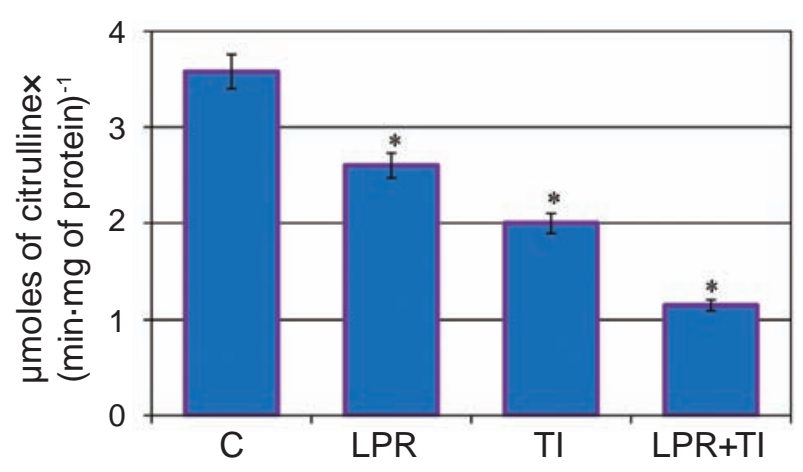

Fig. 3. Argininosuccinate synthase activity in the cytosolic fraction of rat liver cells under the conditions of toxic injury against the background of alimentary protein deficiency. $C$ - animals that were kept on a balanced semisynthetic ration - control group; LPR - animals that received semisynthetic low-protein ration for 28 days; TI - animals with toxic acetaminophen-induced injury maintained on a balanced diet; LPR+TI - animals with toxic acetaminophen-induced injury on the background of alimentary deprivation of protein; * *ignificant difference comparing to control, $P \leq 0.05$

partate shuttle mechanism and directly depends on the structural and functional state of mitochondria. Since the hepatotoxicity of acetaminophen leads to a disruption of the bioenergetic functions of mitochondria (as previously shown [29]), the inhibition of malate-aspartate shunt [30] may be the main cause of the decrease in argininosuccinate synthase activity under these experimental conditions.

Thereby, on the one hand, the reduction of the argininosuccinate synthase activity may be associated with a decrease in the levels of reaction substrates - citrulline and aspartate, on the other hand - with the depletion of cellular energy resources as an essential condition for enzymatic catalysis.

The ornithine cycle uses the energy of the ATP macroergic bonds. Energy expenditure also occurs during the transmembrane transfer of the cycle components (citrulline, ornithine, urea), requiring a constant exchange of hydrophilic metabolites between the cytosol and mitochondria, which have to pass through a voltage-dependent anion channel (VDAC) [31].

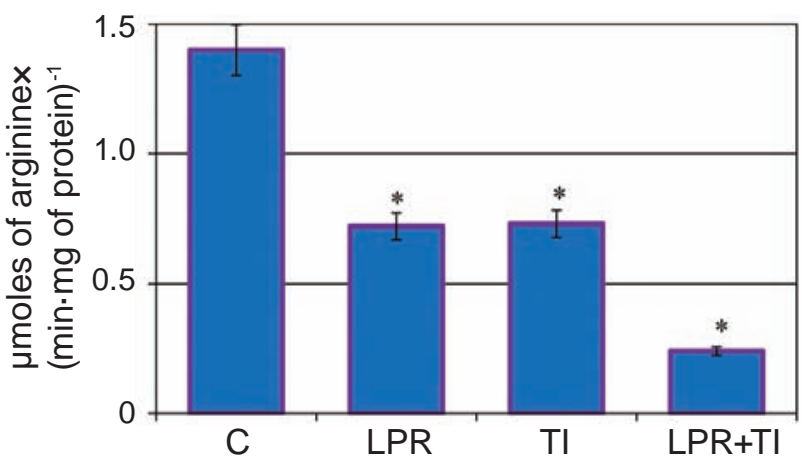

Fig. 4. Argininosuccinate lyase activity in the cytosolic fraction of rat liver cells under the conditions of toxic injury against the background of alimentary protein deficiency. $C$ - animals that were kept on a balanced semisynthetic ration - control group; $L P R$ - animals that received semisynthetic low-protein ration for 28 days; TI - animals with toxic acetaminophen-induced injury maintained on a balanced diet; LPR+TI - animals with toxic acetaminophen-induced injury on the background of alimentary deprivation of protein; * significant difference comparing to control, $P \leq 0.05$

At the same time, similar changes in argininosuccinate lyase activity occur in the cytosol of rat liver cells comparing to the control indexes (Fig. 4). They may be caused by the deficiency of a substrate - argininosuccinate (a product of the previous reaction) and considered as one of the key mechanisms to reduce the arginine levels in hepatocytes under given conditions [11].

Therefore, under conditions of the toxic injury against the background alimentary protein deficiency, there is a decrease in the citrulline levels in rat liver cells, accompanied by the reduction of the activity of argininosuccinate synthase and argininosuccinate lyase, which explains the decrease in the L-arginine level and reflects the disturbances of the urea cycle functioning in hepatocytes.

Conflict of interest. Authors have completed the Unified Conflicts of Interest form at http://ukrbiochemjournal.org/wp-content/uploads/2018/12/ coi_disclosure.pdf and declare no conflict of interest. 


\section{ПОКАЗНИКИ МЕТАБОЛІЗМУ ЦИТРУЛІНУ В ПЕЧІНЦІ ЩУРІВ ЗА УМОВ ТОКСИЧНОГО УРАЖЕННЯ НА ТЛІ АЛІМЕНТАРНОЇ НЕСТАЧІ ПРОТЕЇНУ}

\author{
Г. П. Копильчук, I. М. Николайчук, \\ I. С. Лилик
Чернівецький національний університет імені Юрія Федьковича, Україна; Інститут біології, хімії та біоресурсів, Чернівці, Україна; \\ e-mail: g.kopilchuk@chnu.edu.ua
}

Відомо, що цитрулін під час метаболізму перетворюється на аргінін. Раніше нами було показано, що ацетамінофеніндуковане ураження печінки на тлі аліментарної нестачі протеїну супроводжується зниженням вмісту аргініну в гепатоцитах щура, однак метаболізм цитруліну в печінці за цих умов залишається недостатньо дослідженим. Метою наведеної роботи було оцінити вміст цитруліну та активність ензимів його деградації аргініносукцинатсинтетази та аргініносукцинатліази в мітохондріальній та цитозольній фракціях печінки тварин в умовах ацетамінофеніндукованого ураження печінки на тлі аліментарної нестачі протеїну. Встановлено, що максимальне зниження вмісту цитруліну в мітохондріальній фракції печінки щура спостерігається за введення тваринам токсичних доз ацетамінофену незалежно від кількості протеїну в харчовому раціоні, тоді як аліментарна депривація протеїну виявилась ключовим фактором зменшення рівня цитруліну в цитозольній фракціï. За токсичного ураження на тлі аліментарної нестачі протеїну в цитозольній фракції печінки спостерігалось зниження активності аргініносукцинатсинтетази та аргініносукцинатліази, що свідчить про порушення функціонування циклу сечовини та пояснює зменшення вмісту L-аргініну в гепатоцитах.

К л ю ч о в і с ло в а: L-цитрулін, аргініносукцинатсинтаза, аргініносукцинатліаза, ацетамінофен, токсичне ураження, аліментарна депривація протеїну.

\section{References}

1. Semba RD. The Rise and Fall of Protein Malnutrition in Global Health. Ann Nutr Metab. 2016; 9(2): 79-88.

2. Grover Z, Ee LC. Protein energy malnutrition. Pediatr Clin North Am. 2009; 56(5): 1055-1068.

3. Kompantsev DV, Popov AV, Privalov IM, Stepanova EF. Protein isolates from vegetable raw materials: an overview of the current state and prospects of development of analysis technology of protein isolates from vegetable raw materials. Modern Probl Sci Educ. 2016; (1). (In Russian). Regime of access : http://www. science-education.ru/ru/article/view?id=24132.

4. Agnoli C, Baroni L, Bertini I, Ciappellano S, Fabbri A, Papa M, Pellegrini N, Sbarbati R, Scarino ML, Siani V, Sieri S. Position paper on vegetarian diets from the working group of the Italian Society of Human Nutrition. Nutr Metab Cardiovasc Dis. 2017; 27(12): 1037-1052.

5. Kopylchuk HP, Buchkovska IM, Nikolaev RO. Content of protein fractions of blood plasma in animals under the conditions of protein deficiency. Biolog Syst. 2015; 7(3): 16-20. (In Ukrainian).

6. Maes M, Vinken M, Jaeschke H. Experimental models of hepatotoxicity related to acute liver failure. Toxicol Appl Pharmacol. 2016; 290: 8697.

7. Ben-Shachar R, Chen Y, Luo S, Hartman C, Reed M, Nijhout HF. The biochemistry of acetaminophen hepatotoxicity and rescue: a mathematical model. Theor Biol Med Model. 2012; 9: 55.

8. Kučera O, Endlicher R, Rychtrmoc D, Lotková H, Sobotka O, Červinková Z. Acetaminophen toxicity in rat and mouse hepatocytes in vitro. Drug Chem Toxicol. 2017; 40(4): 448-456.

9. Kopylchuk HP, Buchkovska IM. The state of the glutathione system of liver cells of rats for lowprotein diet and acute hepatotoxic injury. $U k r$ Biochem J. 2014; 86(5, Suppl 1): 165-166. (In Ukrainian).

10. Breuillard C, Cynober L, Moinard C. Citrulline and nitrogen homeostasis: an overview. Amino Acids. 2015; 47(4): 685-691. 
11. Kopylchuk HP, Nykolaichuk IM, Zhuretska OM. Rat liver arginase system under acetaminopheninduced toxic injury and protein deprivation. Ukr Biochem J. 2017; 89(2): 92-98.

12. Bahri S, Zerrouk N, Aussel C, Moinard C, Crenn P, Curis E, Chaumeil JC, Cynober L, Sfar S. Citrulline: from metabolism to therapeutic use. Nutrition. 2013; 29(3): 479-484.

13. Mkhitaryan LS, Kuchmenko OB, Ievstratova IN, Lipkan NG, Vasylynchuk NM, Drobotko TF. Citrulline as a marker of the functional state of organs under pathological conditions. $U k r J$ Cardiol. 2016; (3): 109-115. (In Ukrainian).

14. Mashiko S, Ishihara A, Iwaasa H, Sano H, Ito J, Gomori A, Oda Z, Moriya R, Matsushita H, Jitsuoka M, Okamoto O, MacNeil DJ, Van der Ploeg LHT, Fukami T, Kanatani A. A pairfeeding study reveals that a Y5 antagonist causes weight loss in diet-induced obese mice by modulating food intake and energy expenditure. Mol Pharmacol. 2007; 71(2): 602-608.

15. Reeves PG, Nielsen FH, Fahey GCJr. AIN-93 purified diets for laboratory rodents: final report of the American Institute of Nutrition ad hoc writing committee on the reformulation of the AIN-76A rodent diet. J Nutr. 1993; 123(11): 1939-1951.

16. Stefanov OV. Preclinical studies of drugs. Kyiv: Avicenna, 2001. 527 p. (In Ukrainian).

17. Kopylchuk GP, Voloshchuk OM. NADH:ubiquinone reductase and succinate dehydrogenase activity in the liver of rats with acetaminopheninduced toxic hepatitis on the background of alimentary protein deficiency. Ukr Biochem J. 2015; 87(1): 121-126. (In Ukrainian).

18. Marchenko MM, Kopylchuk GP, Shmarakov IO, Buchkovska IM. Activity of enzymatic detoxification systems in the mice liver under conditions of different retinoid provision. Ukr Biokhim Zhurn. 2012; 84(2): 42-47. (In Ukrainian).

19. Ratner S, Pappas A. Biosynthesis of urea; enzymatic mechanism of arginine synthesis from citrulline. J Biol Chem. 1949; 179(3): 11831198.

20. Archibald RM. Determination of citrulline and allantoin and demonstration of citrulline in blood plasma. J Biol Chem. 1944; 156: 121-142.

21. Lowry OH, Rosebrough NJ, Farr AL, Randall RJ. Protein measurement with the Folin phenol reagent. J Biol Chem. 1951; 193(1): 265-75.
22. Indiveri C, Tonazzi A, De Palma A., Palmieri F. Kinetic mechanism of anti-ports catalyzed by reconstituted ornithine/citrulline carrier from rat liver mitochondria. Biochim Biophys Acta. 2001; 1503(3): 303-313.

23. Giangregorio N, Tonazzi A,Console L, Galluccio M, Porcelli V, Indiveri C. Structure/ function relationships of the human mitochondrial ornithine/citrulline carrier by cys sitedirected mutagenesis. Relevance to mercury toxicity. Int J Biol Macromol. 2018; 120(Pt A): 93-99.

24. Van de Poll MCG, Siroen MPC, van Leeuwen PAM, Soeters PB, Melis GC, Boelens PG, Deutz NEP, Dejong CHC. Interorgan amino acid exchange in humans: consequences for arginine and citrulline metabolism. Am $J$ Clin Nutr. 2007; 85(1): 167-172.

25. Neis EPJG, Sabrkhany S, Hundscheid I, Schellekens D, Lenaerts K, Olde Damink SW, Blaak EE, Dejong CHC, Rensen SS. Human splanchnic amino-acid metabolism. Amino Acids. 2017; 49(1): 161-172.

26. Moinard C, Cynober L. Citrulline: a new player in the control of nitrogen ho-meostasis. J Nutr. 2007; 137(6 Suppl 2): 1621S-1625S.

27. Ivanovski I, Ješić M, Ivanovski A, Garavelli L, Ivanovski P. Metabolically based liver damage pathophysiology in patients with urea cycle disorders - A new hypothesis. World $J$ Gastroenterol. 2017; 23(44): 7930-7938.

28. Saheki T, Kobayashi K. Mitochondrial aspartate glutamate carrier (citrin) deficiency as the cause of adult-onset type II citrullinemia (CTLN2) and idiopathic neonatal hepatitis (NICCD). J Hum Genet. 2002; 47(7): 333-341.

29. Voloshchuk ON, Kopylchuk GP. The State of the adenyl nucleotide system in the liver of rats with toxic hepatitis under conditions of protein deficiency. Biophysics. 2017; 62(6): 980-983.

30. Voloshchuk ON, Kopylchuk GP, Badyak OD. Activity of the liver malate-aspartate shuttle mitochondrial enzymes in rats under the conditions of alimentary deficiency of protein. $J$ Fundam Med Biol. 2015;(2):33-37. (In Russian).

31. Lanpher B, Brunetti-Pierri N, Lee B. Inborn errors of metabolism: the flux from mendelian to complex diseases. Nat Rev Genet. 2006; 7(6): 449-460. 